\title{
AnalAnalisis Hubungan Antara Efikasi Diri dan Intensi Berwirausaha Mahasiswa
}

\author{
Eli Retnowati ${ }^{1 *}$, Arif Rachman Putra ${ }^{2}$ \\ ${ }^{1}$ Universitas Sunan Giri Surabaya \\ ${ }^{2}$ Universitas Mayjen Sungkono Mojokerto \\ *e-mail korespondensi: ny.eliretnowati@gmail.com
}

\begin{abstract}
The form of the problem in Indonesia that still occurs from year to year is the high unemployment rate. One of the causes of unemployment is the lack of job creation. Graduates who have just graduated from their education must compete with other scholars. Moreover, the focus of students today is to find work when they graduate from college. The desire of students to open their own businesses is still lacking in Indonesia. To start opening jobs, self-efficacy and entrepreneurial intention are needed. This study was conducted to analyze and determine the relationship between self-efficacy and entrepreneurial intentions of students in the city of Surabaya. The study used samples from four universities in the city of Surabaya. The sample used is 50 respondents with purposive sampling as a sampling technique. The research data used are the answers to the statements in the distributed questionnaires. The data will be analyzed using correlation and carried out using the SPSS 26 program. This study shows a positive relationship between selfefficacy and students' entrepreneurial intentions.
\end{abstract}

Keywords: self-efficacy, entrepreneurial intentions, students, entrepreneurship

\begin{abstract}
Abstrak: Bentuk permasalahan di Indonesia yang masih terjadi dari tahun ke tahun adalah tingginya tingkat pengangguran. Salah satu penyebab dari pengangguran adalah kurangnya lapangan pekerjaan yang tercipta. Sarjana yang baru lulus dari pendidikannya harus bersaing dengan sarjana lainnya. Terlebih fokus mahasiswa saat ini adalah mencari pekerjaan saat lulus dari bangku kuliah. Keinginan mahasiswa untuk membuka usaha sendiri dirasa masih kurang di Indonesia. untuk memulai membuka lapangan pekerjaan diperlukan efikasi diri dan intensi berwirausaha. Penelitian ini dilakukan untuk menganilisi dan mengetahui hubungan efikasi diri dan intensi berwirausaha mahasiswa di Kota Surabaya. Penelitian menggunakan sampel dari empat perguruan tinggi di kota Surabaya. Sampel yang digunakan berjumlah 50 responden dengan purposive sampling segai teknik pengambilan sampel. Data penelitian yang digunakan merupakan jawaban dari pernyataan yang ada di kuesioner yang disebar. Data tersebut akan dianalisis dengan menggunakan korelasi dan dilakukan menggunakan program SPSS 26. Penelitian ini menunjukkan adanya hubungan yang positif antar efikasi diri dan intensi berwirausaha mahasiswa.
\end{abstract}

Kata kunci: efikasi diri, intensi berwirausaha, mahasiswa, kewirausahaan

\section{PENDAHULUAN}

Perguruan tinggi sebagai tempat untuk menuntut ilmu bagi calon angkatan kerja intelektual yang memiliki peran strategis serta bertanggung jawab untuk 
menciptakan wirausahawan muda. Perguruan tinggi di Indonesia memiliki citra menciptakan lulusan yang siap untuk bekerja dengan kompetensi yang dimiliki. Hasil ini menyebabkan para sarjana bersaing dengan sarjana lainnya untuk merebutkan tempat pada lapangan kerja yang terbatas. Di era pembaruan saat ini perguruan tinggi memulai untuk ikut andil dalam mengurangi pengangguran dengan. Perguruan tinggi diharapkan dapat melakukan upaya untuk memberikan pembelajaran yang berkualitas di perkuliahan agar dapat mengubah karakter lulusan sarjana menjadi pencipta lapangan kerja atau wirausahawan. Menurut Volery et al. (2013), kualitas pendidikan kewirausahaan yang baik akan berkontribusi pada pengembangan sumber daya manusia (SDM) yang mandiri. SDM di perguruan tinggi difokuskan pada kelompok mahasiswa.

Adanya perubahan karakter mahasiswa melalui pendidikan kewirausahaan diharapkan dapat dimanfaatkan bagi mahasiswa yang peka terhadap peluang dan potensi keanekaragaman hayati yang dimiliki Indonesia. Setiap upaya menyampaikan pendidikan kewirausahaan mengarahkan pada penciptaan wirausahawan muda yang mampu menciptakan pekerjaan dan memiliki kemampuan untuk mengeksplorasi potensi sumber daya alam. Karakteristik individu memiliki pengaruh yang signifikan efektivitas kerja.

Jumlah pencari kerja yang terus meningkat dan lapangan kerja yang tidak mencukupi serta adanya persaingan yang kompetitif di dunia kerja mengakibatkan kaum usia muda khususnya mahasiswa terpaksa menerima pekerjaan yang tidak sesuai dengan keinginan, kemampuan, pengetahuan mereka atau bahkan menjadi pengangguran. Masalah pengangguran yang merupakan masalah ekonomi secara makro dapat diatasi yang salah satu caranya mendorong pertumbuhan wirausahawanmuda karena kaum usia muda cenderung mempunyai daya kreativitas yang tinggi. Kreativitas telah menjadi isu sentral pada upaya memahami perilaku kewirausahaandalam ekonomi global (Rumble dan Minto, 2017; Camacho-Miñano dan Del Campo, 2017). Selain itu, kreativitas memiliki pengaruh terhadap perilakuberwirausaha di negara berkembang dikarenakan adanya pengangguran pada kaumusia muda, kemiskinan, kejahatan sosial (Bhalla dan Lapyre, 2016). 
Pemerintah melalui Program Mahasiswa Wirausaha (PMW) berusaha mendorong mahasiswa belajar berwirausaha. Hal ini mendapat hambatan dari rendahnya niat dan tekad untuk berwirausaha. Sebelum niat itu muncul dalam diri seseorang seharusnya ada motivasi untuk mencapai kesuksesan. Bentuk kepercayaan diri seseorang akan meningkatkan kemampuan untuk mengendalikan diri dengan baik dipengaruhi faktor keinginan dari orang itu sendiri untuk melakukan capaian pada hidupnya. Seorang wirausaha yang percaya pada kompetensi yang dimiliki dan dapat menunjukkan capaian yang tinggi dikatakan telah mempunyai efikasi diri yang baik ( Hisrich et al.2008). Filosofi ini menjelaskan capaian seseorang akan berhasil dipengaruhi oleh efikasi diri. Efikasi diri yang tinggi memunculkan pengaruh untuk berinisiatif dan berusaha lebih tekun menjadi wirausahawan dan sebaliknya efikasi diri dengan kadar yang rendah berdampak pada kurangnya keinginan dan semangat diri. Efikasi diri memberikan pengaruh terhadap keputusan bisnis apa yang akan dijalani serta seberapa besar bisnis tersebutakan dimulai dari awal. Antusiasme wirausaha akan terlihat sebanding dengan efikasi diri pada wirausaha yang menjalankan usaha baru, kemudian dengan baiknya efikasi diri akan memunculkan intensi berwirausaha. Intensi berwirausaha berperan penting untuk perkembangan ekonomi dan masyarakat (Audretsch dan Fritsch, 2002; Carreeet al., 2002).

Bandura (1997) menjelaskan prestasi seseorang dipengaruhi dari efikasi diri yang dimiliki. Perilaku manusia merupakan hasil dari kombinasi perilaku individu, lingkungan sekitar, dan pengaruh dari intrapersonal. Kombinasi ini akan mendorong terbentuknya keyakinan yang dimiliki seseorang tentang kemampuan yang dimiliki sehingga mampu bereaksi terhadap keadaan yang sedang terjadi. Perilaku seseorang mengenai sebuah kondisi seperti mengambil keputusan di suasana tertentu akan dipengaruhi oleh tingkatan kemampuan efikasi diri yang dipunya. (Bandura, 1997; Dwyer dan Cummings, 2001). Pengaruh mendasar dari efikasi diri pada perilaku manusia menjadikan para sarjana menerapkan konsep ini di berbagai bidang seperti kewirausahaan. Para ahli berpendapat bahwa pemilihan kejuruan adalah proses kompleks yang membutuhkan rasa efikasi diri yang tinggi (Bryant 2007; Schjoedt dan Shaver 2007). Efikasi diri pada bidang 
kewirausahaan adalah kemampuan yang diyakini wirausaha untuk mampu menyelesaikan tugas dan peran wirausahawan dan harapannya serta cita-cita terhadap resiko menciptakan usaha baru (Kickul et al,. 2008; Barnir et al., 2011; Kickul et al,. 2008; McGee et al., 2009; Chen et al., 1998). Sebelumnya beberapa hasil penelitian menunjukkan niat dan kompetensi seorang wirausaha dipengaruhi oleh efikasi diri wirausaha tersebut, terbukti dengan efikasi baik maka kelompok wirausaha lebih antusias menciptakan usaha baru, tidak menyerah dengan tantangan dunia usaha, selalu mampu beradaptasi pada kebijakan bisnis, serta keberhasilan saat melakukan tugas dan kewajibannya sebagai wirausaha (Chen et al., 1998; Trevelyan 2011). Karakteristik efikasi diri wirausaha penting untuk mengeksplorasi niat usaha baru dan memiliki niat kewirausahaan yang kuat dengan meningkatkan efikasi diri tersebut melalui pelatihan dan pendidikan yang dilakukan dengan efektif dan dapat diaplikasikan langsung terutama bagi mahsiswa (Barbosa et al., 2007; Mueller dan Goic, 2003; Zhao et al., 2005; Boyd dan Vozikis, 1994).

Berdasarkan uraian sebelumnya menunjukkan adanya indikasi hubungan atau kaitan efikasi diri dengan intensi berwirausaha. Hal tersebut ditunjukkan denganstudi sebelumnya dari Chen et al. (1998); Zhao et al. (2005); Kickul et al. (2009); Drnovšek et al. (2010); Arora et al. (2013); Sanchez (2013); Bullough et al. (2014); Malebana dan Swanepoel (2014); Piperopoulos dan Dimov (2015); Urban (2016). Dengan demikian, studi ini bertujuan untuk mengetahui hubungan antara efikasi diridan intensi berrwirausaha pada diri mahasiswa.

\section{METODE}

Penelitian ini merupakan jenis penelitian survei dan ex post facto. Penelitian survey merupakan bagian riset yang dapat dilakukan pada keadaan populasi yang kecil dan besar namun digunakan sampel yang diperoleh dari bagian populasi tersebut, sehingga akan didapatkan kejadian relative yang dapat melihat hubngan antar variabel. Penelitian ex post facto merupakan penelitian yang tidak dapat dimanipulasi karena variabel bebas pernah diteliti atau tidak diciptakan sendiri oleh peneliti sehingga jenis penelitian ini dapat disebut dengan penilitian empiris. Populasi di penelitian ini merupakan mahasiswa yang berasal dari empat 
perguruan tinggi yang ada di Kota Surabaya. Sampeldigunakan berjumlah 50 responden. Teknik pengambilan sampelnya adalah purposive sampling. Variabel yang diteliti ada dua yaitu variabel efikasi diri dan intensi berwirausaha mahasiswa. Penjelasan kedua variabel tersebut, yaitu:

a. Efikasi diri merupakan kepercayaan yang dimiliki oleh mahasiswa sehingga mampu melaksanakan tugas serta berhasil menyelesaikan harapan yang diinginkan. (Bandura, 1997; McGee et al., 2009; Ormrod, 2009). Efikasi diri memiliki tiga dimensi, yaitu (1) Generality; (2) level atau magnitude; dan (3) strenght ( Bandura, 1997).

b. Intensi Berwirausaha adalah keyakinan, pengorbanan dan keputusan mahasiswa yang disengaja yaitu segera membuka usaha baru agar selalu meningkat dan mampu mencapai tujuan yang diinginkan (Gupta dan Bhawe, 2007; Wilson et al., 2007; Peng et al., 2012; Solesvik et al., 2012). Ajzen (1991) menentukan tiga dimensi intensi berwirausaha, yaitu (1) sikap berperilaku; (2) norma subjektif; dan (3) kontrol perilaku (Ajzen, 1991).

Kuesioner disusun berdasarkan skala Likert dengan skala satu (sangat tidak setuju sekali) hingga delapan (sangat setuju sekali). Dari permasalahan, tujuan, serta dugaan yang terjadi maka penelitian ini menggunakan teknik analisis korelasi sebagai metode statistik yang digunakan. Analisis data akan diolah menggunakan SPSS versi 26. Sebelum dilakukan analisis data perlu diuji kualitas dari data yang digunakan. Untuk itu dilakukan uji validitas dan uji reliabilitas.

\section{HASIL DAN PEMBAHASAN}

\section{Hasil}

Akurasi dari daftar pernyataan yang tertulis pada kuesioner akan diuji dengan tes validitas. Penetapan validnya suatu pernyataan digunakan dapabila corrected item total correlation yang diperoleh lebih tinggi dari nilai 0,3 . Berdasarkan output SPSS terbukti variabel-variabel yang terlibat di penelitian ini tidak memiliki item pertanyaan yang digugurkan sebab hasil validitas semua pernyataan sesuai dengan kriteria yang telah ditetapkan. Dengan hasil ini semua item pernyataan yang digunakan pada kuesioner penelitian ini dinyatakan valid.

Untuk membuktikan alat ukur yang digunakan andal maka perlu dilakukan 
tes reliabilitas. Untuk variabel efikasi diri didapatkan alpha bernilai sebesar 0,862. Variabel intensi berwirausaha didapatkan alpha bernilai sebesar 0,803. Nilai alpha didapatkan lebih besar dari 0,6 dengan ini dapat dinyatakan alat ukur yang digunakan pada penelitian ini reliabel.

Pada Tabel 1 menunjukkan nilai KS efikasi sebesar 0,152 serta nilai signikan sebesar 0,55 ( $p>0,05)$. Nilai KS intensi sebesar 0,094 dengan nilai signifikan sebesar 0,2 ( $p>0,05)$. Nilai tersebut menyatakan bahwa kedua variabel memiliki distribusi data secara normal. Nilai standar deviasi untuk efikasi diri sebesar 6.685 kurang dari nilai rata-rata variabel efikasi diri sebesar 62.14. Nilai standar deviasi untuk intensi berwirausaha 4.544 maka standarnya kurang dari nilai yang dijadikan standar oleh intensi berwirausahasebesar 37.08.

Tabel 1. One-Sample Kolmogorov-Smirnov

Test

\begin{tabular}{llrr}
\hline & & EFIKASI & INTENSI \\
\hline $\mathrm{N}$ & & 50 & 50 \\
\hline Normal Parameters $^{\mathrm{a}}$ & Mean & 62.14 & 37.08 \\
\cline { 2 - 4 } & Std. Deviation & 6.685 & 4.544 \\
\hline Most Extreme & Absolute & .152 & .094 \\
\cline { 2 - 4 } Differences & Positive & .150 & .094 \\
\cline { 2 - 4 } & Negative & -.152 & -.084 \\
\hline Kolmogorov-Smirnov Z & & .152 & .094 \\
\hline Asymp. Sig. (2-tailed) & & .055 & .200 \\
\hline a. Test distribution & is & &
\end{tabular}

Normal. Sumber hasil olah

SPSS

Hasil korelasi dari efikasi diri serta intensi berwirausaha disajikan Tabel

2. Hasilnya menunjukkan bahwa korelasi di antara variabel efikasi diri dan intensi berwirausaha memiliki nilai sejumlah 0,820 dengan signifikan yang didapatkan sebesar 0,000. Angka yang telah dihasilkan ini menunjukkan efikasi diri dengan intesi berwirausaha memiliki hubungan yang positif. Dapat disimpulkan efikasi diri yang tinggi akan memperkuat intensi berwirausaha, sebaliknya lemahnya intensi berwirausaha diakibatkan dari efikasi diri yang 
rendah. Selanjutnya dapat dipastikan bahwa 50 responden telah mempunyai efikasi diri yang baik untuk berwirausaha.

Tabel 2. Korelasi Antar Variabel

\begin{tabular}{llrr}
\hline & & INTENSI & \multicolumn{1}{c}{ EFIKASI } \\
\hline INTENSI & Pearson Correlation & 1 & $.820^{* *}$ \\
\cline { 2 - 4 } & Sig. (2-tailed) & 50 & .000 \\
\cline { 2 - 4 } & $\mathrm{N}$ & $.820^{* *}$ & 50 \\
\hline EFIKASI & Pearson Correlation & .000 & 1 \\
\cline { 2 - 4 } & Sig. (2-tailed) & 50 & 50 \\
\cline { 2 - 4 } & $\mathrm{N}$ & &
\end{tabular}

**. Correlation is significant at the 0.01 level (2-tailed)

\section{Pembahasan}

Penelitian menghasilkan efikasi diri memiliki hubungan positif terhadap intensi berwirausaha. Pernyataan ini diperoleh melalui analisis data yang telah dilakukan serta jawaban dari sebaran kuesioner yang dilakukan oleh peneliti.

Hasil analisis pada riset yang telah dilakukan diketahui hubungan efikasi dan intensi berwirausaha merupakan hubungan yang positif. Hal tersebut sesuai studi sebelumnya (Chenet al. 1998; Malebana dan Swanepoel, 2014; Zhao et al. 2005; Kickul et al. 2009; Drnovšek et al. 2010; Arora et al.2013; Sanchez, 2013; Bullough et al. 2014; Piperopoulos dan Dimov, 2015; Urban, 2016). Wirausaha yang mempunyai efikasi diri tinggi maka intensi berwirausahanya juga semakin kuat. Pihak manajemen dapat (1) menekankan perlunya mengintegrasikan variabel kognitif selain efikasi diri seperti kreativitas teknologi. Adanya kreativitas teknologi dan stimulasi efikasi diri pada kurikulum pembelajaran di perguruan tinggi diharapkan dapat meningkatkan dan mempertahankan wirausahawan yang potensial.

Kreativitas teknologi sebagai solusi masalah kehidupan secara nyata dan praktis, orientasi yang kuat menuju peningkatan produktivitas dan penekanan pada peran pengaruh lingkungan atau pengaruh konstekstual berkontribusi untuk meningkatkan niat kewirausahaan dan menciptakan usaha baru; (2) 
pendekatan secara inovatif, pendekatan ini dilakukan untuk menghadapi tantangan baru dan hal ini dapat dilakukan dengan membuka atau memperkenalkan kelas khusus pembelajaran kewirausahaan secara individu dan kelompok dimana kegiatan tersebut meliputi identifikasi masalah dan pemecahan masalah (seperti pembelajaran melalui simulasi). Simulasi dan pembelajaran berbasis masalah diharapkan dapat meningktakan kemampuan mahasiswa untuk menghasilkanlebih banyak ide dan solusi untuk menghadapi permasalahan nyata (Schmidt et al., 2013); (3) membentuk program yang bertujuan dan memilki efektifitas bagi mahasiwa dengan pendidikan dan pelatihan pada bidang kewirausahaan untuk meningkatkan kemampuan mereka ketika melakukan tugas atau peran sebagai wirausahawan yang dapat melibatkan mahasiswa pada berbagai kesempatan belajar sepertipenulisan rencana bisnis, permodelan peran dan studi kasus (Chen et al., 1998; Fayolle et al., 2006; Wilson et al., 2007); (4) pembelajaran yang diberikan tidak hanya dengan teori atau dengan pengajaran yang konvensional, tetapi juga memberikan area yang menantang namun bisa mendukung mahasiswa data menjalankan usaha baru.

\section{SIMPULAN}

Dari hasil analisis yang telah dilakukan dengan pembahasan maka peneliti dapat memberikan simpulan diketahui hubungan yang positif diantara efikasi diri dan intensi berwirausahamahasiswa. Peningkatan efikasi diri dan intensi berwirausaha dilakukan dengan dengan (1) inisiatif pengembangan keterampilan melalui pendidikan kewirausahaan yang terencana dan diterapkan secara terus-menerus sehingga mahasiswa dapat mandiri, berani mengambil resiko; (2) pendidikan kewirausahaan yang diberikan harus didukung dengan penerapan atau praktik secara langsung, sehingga mahasiswa berani untuk mencoba dan mengambil keputusan untuk berwirausaha; (3) perguruan tinggi bekerjasama dengan lembagayang dapat mendukung kegiatan berwirausaha mahasiswa; (4) melaksanakan program untuk menindaklanjuti dan mengevaluasi efektivitas pelatihan dan pendidikan yang telah diberikan kepada mahasiswa; (5) mengadakan seminar dan pelatihan kewirausahaan berbasis digital entrepreneurship. Kewirausahaan digitalmenciptakan usaha baru dan 
merubah usaha yang telah ada dengan mengembangkan teknologi digital baru atau penggunaan teknologi baru.Kewirausahaan digital telah dipandang sebagai sesuatu hal yang penting untuk pertumbuhan ekonomi, menciptakan lapangan kerja dan inovasi.

\section{DAFTAR RUJUKAN}

Ajzen, I. 1991. The Theory of Planned Behavior, Organizational Behavior and Human Decision Processes, 50, 179-211.

Arora, P., Haynie, J.M. \& Laurence, G.A. 2013. Counterfactual Thinking and Entrepreneurial Self-efficacy: The moderating role of self-esteem and dispositional affect. Entrepreneurship: Theory and Practice 37(2), 359385.

Audretsch, D. B. \& Fritsch, M. 2002. Growth Regimes Over Time and Space. Regional Studies, 36(2), 113-124.

Bandura, A. 1997. Self-efficacy: The exercise of control. New York: W.H. Freemanand Company.

Barbosa, S. D., Gerhardt, M. W. \& Kickul, J. R. 2007. The Role of Cognitive Style and Risk Preference on Entrepreneurial Self-efficacy and Entrepreneurial Intentions. Journal of Leadership and Organizational Studies, 13(4), 86- 104.

Barnir, A., Watson, W. E., \& Hutchins, H. M. 2011. Mediation and Moderated Mediation in the Relationship Among Role Models, Self-efficacy, Entrepreneurial Career Intention, and Gender. Journal of Applied Social Psychology, 41(2), 270-297.

Bhalla, A.S. \& Lapeyre, F. 2016. Poverty and Exclusion in a Global World, Palgrave MacMillan, London

Bryant, P. 2007. Self-regulation and Decision Heuristics in Entrepreneurial Opportunity Evaluation and Exploitation. Management Decision, 45(4), 732-748.

Bullough, A., Renko, M. \& Myatt, T., 2014, Danger Zone Entrepreneurs: The importance of resilience and self-efficacy for entrepreneurial intentions. 
Entrepreneurship Theory \& Practice, 38(3), 473-499.

Camacho-Miñano, M.D.M. \& Del Campo, C., 2017. The Role of Creativity in Entrepreneurship: An empirical study on business undergraduates. Education and Training 59(7/8), 672-688.

Carree, M., Van Stel, A., Thurik, R. \& Wennekers, S. 2002. Economic Development and Business Ownership:an analysis using data of 23 OECDcountries in the period 1976-1996. Small Business Economics, 19(3), 271- 290.

Chen, C.C., Greene, P.G. \& Crick, A. 1998. Does Entrepreneurial Self-efficacy Distinguish Entrepreneurs from Managers? Journal of Business Venturing.13(4), 295-316.

Drnovšek, M., Wincent, J. \& Cardon, M.S. 2010. Entrepreneurial Self-efficacy and Business Start-up: Developing a multi-dimensional definition. InternationalJournal of Entrepreneurial Behavior \& Research, 16(4), 329-348.

Dwyer, A. L. \& Cummings, L. C. 2001. Stress, Self-efficacy, Social Support and Coping Strategies in University Students. Journal of Counselling, 35, (3). Fayolle, A. \& Gailly, B. 2008. From Craft to Science: teaching models and learningprocesses in entrepreneurship education. Journal of European Industrial Training, 32(7), 569-593

Fayolle, A., Gailly, B. \& Lassas-Clerc, N. 2006. Assessing the Impact of Entrepreneurship Education Programmes: a new methodology. Journal of European Industrial Training, 30(9), 701-720.

Gupta, V., \& Bhawe, N.2007. The Influence of Proactive Personality and Stereotype Threat on Women's Entrepreneurial Intentions. Journal of Leadership \& Organizational Studies, 13(4), 73-85.

Hisrich, R.D., Peter, M.P. \& Shepherd, D.A. 2008. Entrepreneurship. Chriswan Sungkono dan Diana Angelica (translation), Kewirausahaan, Salemba Empat, Jakarta.

Kickul, J., Gundry, L.K., Barbosa, S.D. \& Whitcanack, L. 2009. Intuition Versus Analysis? Testing Differential Models of Cognitive Style on 
Entrepreneurial Self-Efficacy and the New Venture Creation Process. Entrepreneurship Theory and Practice, Blackwell Publishing Inc, 33 (2), 439-453.

Kickul, J., Wilson, F. \& Marlino, D. 2008. Are Misalignments of Perceptions and Self-efficacy causing Gender Gaps in Entrepreneurial Intentions Among our Nation's teens? Journal of Small Business and Enterprise Development, 15(2), 321-335.

Malebana, M.J. \& Swanepoel, E. 2014. The Relationship between Exposure to Entrepreneurship Education and Entrepreneurial Self-efficacy. Southern African Business Review, Promedia, 18 (1), 1-26.

McGee, J., Peterson, M., Mueller, S., Sequeira, J. 2009. Entrepreneurial SelfEfficacy: Refining the Measure. Entrepreneurship, Theory and Practice, 965-988

Mueller, S. L. \& Goić, S. 2003. East-West Differences in Entrepreneurial Selfefficacy: Implications for Entrepreneurship Education in Transition Economies. International Journal for Entrepreneurship Education,1(4), 613-632.

Ormrod, J. E. 2009. Principles of Educational Psychology,Toronto, Pearson Prentice Hall.

Peng, Z., Lu, G. \& Kang, H. 2012. Entrepreneurial Intentions and its Influencing Factors: A survey of the university students in Xi'an China. Creative Education 3, 95-100

Piperopoulos, P. \& Dimov, D. 2015. Burst Bubbles or Build Steam? Entrepreneurship Education, Entrepreneurial Self-Efficacy, and Entrepreneurial Intentions. Journal of Small Business Management, 53 (4),970-985.

Rumble, R. \& Minto, N.A., 2017. How to Use Analogies for Creative Business Modelling. Journal of Business Strategy, 38(2), 76-82

Sanchez, J.C. 2013. The Impact of an Entrepreneurship Education Program on Entrepreneurial Competencies and Intention. Journal of Small Business Management, 51 (3), 447-465. 
Schjoedt, L. \& Shaver, K. G. 2007. Deciding on an Entrepreneurial Career: a test of the pull and push hypotheses using the panel study of entrepreneurial dynamics data. Entrepreneurship Theory and Practice, 31(5), 733-752.

Schmidt, J.J., Soper, J.C. \& Bernaciak, J. 2013. Creativity in the Entrepreneurship Program: A survey of the directors of award winning programs. Journal of Entrepreneurship Education,16 (1), 31-45

Trevelyan, R. 2011. Self-regulation and Effort in Entrepreneurial Tasks. International Journal of Entrepreneurial Behavior \& Research, 17(1), 39-63.

Urban, B. 2016. Evaluation of Social Enterprise Outcomes and Self-efficacy. International Journal of Social Economics, 42(2), 163-178.

Volery, T, Muller, S, Oser, F, Naepflin, C. \& Rey, N. 2013. The Impact of Entrepreneurship Education on Human Capital at Upper Secondary Level. Journal of Small Business Management, 51(3), 429-446.

Wilson, F., Kickul, J. \& Marlino, D. 2007. Gender, Entrepreneurial Self-efficacy, and Entrepreneurial Career Intentions: implications for entrepreneurship education. Entrepreneurship Theory and Practice, 31(3), 387-401.

Zhao, H., Seibert, S. E. \& Hills, G. E. 2005. The Mediating Role of Self-efficacy in the Development of Entrepreneurial Intentions. Journal of Applied Psychology, 90(6), 1265-1272. 